\title{
An Examination of the U.S. Military Intervention Against the Islamic State in Iraq
}

\author{
Hoshman A. Mahmod ${ }^{1}$, Arez A. Abdullah² \\ ${ }^{1}$ Department of Social Sciences, College of Basic Education, Halabja University \& Department of International Relations and Diplomacy, Faculty \\ of Administrative Sciences and Economics, Tishk International University-Sulaimani, Kurdistan Region, Iraq \\ ${ }^{2}$ Directorate of Foreign Relations, Ministry of Culture and Youth, Erbil, Kurdistan Region, Iraq
}

\begin{abstract}
This article focuses on the politics of U.S. intervention in war against the Islamic State in. In the last two decades, the U.S. intervened in many countries in different ways. For example, the U.S. forces and allies fully intervened in Afghanistan in 2001 and Iraq in 2003. Hence, after the dynamic changes in the Middle East and Arab spring, the intervention has changed differently. When the terrorist organizations rose, the U.S. has followed the same policy used in the Kosovo War (1999) against the Islamic State, which was not fully intervened. U.S. public opinion plays a significant role in U.S. politics. Regional and international relations between countries are crucial. It is worthwhile to address Turkey, Iran, and Kurdish forces in regional considerations because they all border with the Islamic State which directly and indirectly impacted them. In international considerations, the U.S. usually makes a coalition and alliance to intervene in countries and groups. The purpose of the study is to understand the politics of U.S. intervention in war against the Islamic State. It examines from three perspectives, firstly, a change in the U.S. policy of intervention; secondly, the U.S. domestic political considerations; thirdly, Regional and International considerations. Following this evaluation, this study answering the question: Why has the U.S. not fully intervened against the Islamic State? This research concludes that the U.S. should change its policy of intervention from one time to another. The U.S. should change its military tactics from one war to another war. The American government should understand how its domestic politics and other countries feel about the politics of U.S. intervention in war against Islamic State. The results show that the politics of U.S. intervention is complex. However, there is still a way to understand it.
\end{abstract}

KEY WORDS: Islamic State, Kurdish Forces, Politics of U.S. Intervention, Turkey \& Iran, U.S. Public Opinion

\section{INTRODUCTION:}

The U.S. intervention has been prominent in terms of political objectives and international relations. Since the end of the Cold War, the U.S. has intervened in many countries around the world. According to Jentleson and Britton (1998), U.S. military forces have been deployed

Koya University Journal of Humanities and Social Sciences (KUJHSS), Volume 4, Issue 1, 2021.

Received 17 Feb 2021; Accepted 20 Jun 2021, Regular research paper: Published 30 Jun 2021

Corresponding author's e-mail: hoshman.mahmod@uoh.edu.iq Copyright (2021. Hoshman A. Mahmod, Arez A. Abdullah, this is an open access article distributed under the Creative Commons Attribution License. in many countries since the end of the Cold War. From 1992 to 1994, the U.S. sent 27,000 troops to Somalia, part of Operation Restore Hope. From 1994 to 1996, the U.S. sent 20,000 troops to Haiti to change the regime and restore Jean Bertrand Aristide's power. The U.S. sent the 20,000 soldiers in 1995 as part of NATO's implementation force (IFOR), and 7,000 soldiers were left by the U.S. between 1996 to 1998 as part of the stabilization force (SFOR). The U.S. also conducted airstrikes and patrolled the no-fly zone in Bosnia for three years. The U.S. sent 1,500 troops to Macedonia as part of a United Nations (U.N.) against Serbia (Jentleson \& Britton, 1998 p: 395,396).

In the past and most cases, the U.S. fully intervened in countries with its troops, warships, and air forces. However, the politics of U.S. intervention changed over 
the Islamic State's case, which intervened without ground troops. For example, the U.S. intervention in Iraq in 2003 was a full intervention with its forces deployed in the country, while the U.S. has intervened in the Islamic State conflict without its ground troops and just by bombing. Sprusansky (2014) states that the Islamic State has several names and acronyms regarding its reputation. The group itself refers to the Islamic State (I.S.). In many Western countries, the group has announced the Islamic State of Iraq and Syria or ISIS. The American government and some media have used the Islamic State of Iraq and Levant or ISIL. Others call the group the Islamic State of Iraq and al-Sham. In the Arabic world, the group is referred to as "al-Dawla alIslamiya fi Iraq wa al-Sham (Da'ish)."

This research methodology is a qualitative approach. We examined the US interventions two decades after the Cold War, and the late intervention in war against Islamic State. It is hypothesized that the United States no longer wants to be directly involved in messy little wars in the Middle East because of some factors such as domestic, international, and regional factors. Theoretically, although we take a realist approach to international relations, analysts usually view strategic interests as the determining factor of U.S. foreign policy which considers national interests in terms of power and security. The rise of ISISS, however, was a threat to American power in the Middle East. It threatened the American allies like Israel and the Arab States in Gulf. It would spread Islamic extremism and radicalism in Muslim majority countries, and also it was a threat to American security both inside the United States and abroad. Ordinary people still remember September, 11 and the rise of Al-Qaida. Moreover, it was a threat to American prosperity as so many American economic corporations in the region. For that reason, military intervention was the best option for the Obama administration but this time in a different way.

There is much confusion about the Islamic State and the politics of the U.S. intervention in international affairs. There is also a considerable debate about changing the way of U.S. intervention. The U.S. should not fully intervene in some countries because the U.S. lost internal support, such as the U.S. public opinion, and external support like the U.K.'s support. If the U.S. loses internal and external supports and the U.S. does not intervene in countries anymore, the U.S. will start to decline and lose its position as player number one or superpower in the world. So, the hegemon always needs a crisis which is called "the search for the enemy" by Huntigton (2004, P 258). Thus, the U.S. tries to find another way to intervene in countries that are not entirely in intervention, such as the American-led conflict against the Islamic State Caliphate. This study aims to analyze the politics of U.S. intervention in war against the Islamic State and examine why the politics of U.S. intervention is incoherent towards Islamic State. The research question is why has the U.S. not fully intervened in war against the Islamic State? Besides, it will evaluate a change in the U.S. policy of intervention. Then it will explain the U.S. domestic political considerations concerning I.S. Additionally, it discusses regional and international considerations about I.S. In this study, the analytical method is adopted by analyzing the documents and the arguments made in the literature. It also relies on some personal speech.

\section{A CHANGE IN THE U.S. POLICY OF INTERVENTION IN TERMS OF THE UTILITY OF FORCE}

Since the end of the cold war period, the U.S. has led the world by itself. Also, in the last two decades or more, the USA intervened in many countries differently. For instance, The U.S. fully intervened in Afghanistan in 2001 and Iraq in 2003. It used its air force, naval and ground troops. Codner (2014) notes that America had a significant role in the operation of Anaconda against the Taliban and Al-Qaida with Britain in Afghanistan in 2001; likewise, in the Iraq war in 2003 (Codner, 2014). However, the U.S. did not fully intervene in the Kosovo war in 1999. It used its air power with the ground troops of local allies. Keohane (2000) states that the U.S. and the U.K. took a big part in intervention in Kosovo in 1999 (Keohane, 2000). Likewise, the U.S. has not fully intervened against ISIS. The U.S. has intervened in war against ISIS only by bombing without its ground soldiers. According to Mint (2014), after ISIS threatened millions of people in Iraq and Syria and killed many Kurds, America intervened in the war in August 2014 by bombing. When ISIS came to Iraq, when Iraqis cried to the world and said, "There is no one coming to help." President Barack Obama answered on television late night on 07 August 2014, and he said, "Well, today America is coming to help." Also, he said, "We can act carefully and responsibly to prevent a potential act of genocide." August 8, 2014 was the first day, and two American warplanes bombed the Islamic State's fighters near Erbil, the capital of Iraqi Kurdistan's regional government. American President said, "Washington must act to prevent 'genocide'" (Mint, 2014 p: 1). Consequently, it can be argued that the U.S. policy of intervention has changed over time. This shows that the U.S. fully intervened in countries in some cases, and in other cases, the U.S. did not fully intervene in countries.

According to Smith (2006), war changes from one 
battle to another and from one time to another because the enemy and its tactic change. Smith highlights that in some cases, forces have not been employed although they have been deployed as was the case of U.N. in the Balkans. In 1995, tens of thousands of the U.N. army were based in Croatia and Bosnia. However, the Security Council banned troops from using any real military force. Sometimes force has been employed, but with little effect, for example, in the no-fly zones over Iraq before the Iraq war in 2003. A coalition aircraft hit the Saddam Hussein regime from 1990 to 1991, but there was very little consequence with the Iraqi regime's horrors.

The great force has been employed; however, the results have been less than strategically conclusive. The prime example was the Gulf War in 1991 and Chechnya in 2000. Although the military intervention was successful, the essential strategic issue remained unresolved. In the other cases, the force has been applied so that its target was difficult to illustrate to allies, for instance, Kosovo in 1999 and Iraq in 2003 (Smith, 2006, p: 4,5). Also, MacMillan observes that "... the practice of intervention has changed over time..." (2013, p: 1041). These show that while the military operation has changed over time, the U.S. military operation has also changed. As a result, the U.S. military operation has changed from one war and day to another because its enemy tactic changed over time. Nowadays, the Islamic State does not let the U.S. use the same successful tactics, which the U.S. had used before. ISIS is a different enemy for the U.S., and its military tactics are also different from other cases.

\section{THE U.S. INTERVENTION IN AFGHANISTAN (2001) AND IRAQ (2003)}

The U.S. forces and its allies fully intervened in Afghanistan in 2001 and Iraq in 2003. America, with its partners, intervened in both of them by its airstrikes and ground soldiers. However, the Afghan war was not the same as the Iraq war in military intervention. According to Kurth (2005), the U.S. intervened in Afghanistan (2001) and Iraq (2003) by its troops and its air powers. In 2001 in the Afghan war, the U.S. used its air forces and special ground troops (Kurth, 2005). Codner (2014) states that the U.S. and the U.K. fully intervened in Iraq in 2003. They used their intelligence, a naval and air commitment of around '90 front-line aircraft, 20 warships, with 13,000 personnel all told'. They used ground troops, 'over 300 tanks/armored vehicles and 28,000 personnel' (Codner, 2014, p: 57). Consequently, it will be argued that the U.S., with its coalition, entirely operated in Afghanistan in 2001 and Iraq in 2003. In contrast, it has not entirely operated against I.S. with its allies because they only bombed I.S. by their air forces .

\section{THE U.S. INTERVENTION IN BOSNIA (1995) AND KOSOVO (1999)}

The U.S. has intervened against ISIS, similar to its work in the Bosnian war of 1995 and the Kosovo war of 1999. The U.S. intervened in Bosnia in 1995 and Kosovo in 1999 by its airpower without deploying its troops. According to Kurth (2005), the U.S. used its air forces with local allies' ground soldiers in Bosnia and Kosovo as the Croatian troops. Also, the U.S. won these wars (Kurth, 2005). As a result, it may be argued that these successes encourage the Americans to continue on this new war tactic. The U.S. won wars with few American casualties, and these were a cheap success. The U.S. has also repeated the same way, used in the Bosnia war (1995) and the Kosovo war (1999), against I.S.

\section{THE U.S. INTERVENTION AGAINST THE ISLAMIC STATE}

The U.S. has not fully intervened against the Islamic State. The Islamic State has controlled vast areas in Syria and Iraq. In addition, I.S. has terrorized and killed many Syrian, Iraqi, and Kurdish civilian people. For example, the I.S. genocide against Kurdish Yazidis, an ethnic and religious minority in Iraq's Kurdistan region. However, so far, Washington has limited its operations against ISIS to an actual attack. Phillips (2015) observes that after the Islamic State seized Mosul on 10 June 2014, I.S. sent a message to the Kurdistan Regional Government (KRG): "If you do not attack us, we will not attack you."

Nonetheless, I.S. fighters started to attack Kurds in the Syrian cities of Kobani and Hasakah. Then, I.S. attacked Sinjar in Iraq's Kurdistan on 03 August 2014 (Phillips, 2014, p: 352). On 09 August 2014, I.S. overran Makhmour just 30 kilometers south of Erbil, the Iraqi Kurdistan Regional Government's capital. On 09 August 2014, the U.S. began to bomb ISIS (Phillips, 2015, p: 353). Consequently, it can be argued that the U.S. has not fully intervened in the ISIS situation. Washington has attacked ISIS as similar as Kosovo in 1999. The U.S. would like to spend very few American casualties and money. This type of war could be seen as a humanitarian intervention. It shows that the politics of U.S. intervention have changed from full intervention to incomplete intervention.

\section{THE U.S. DOMESTIC POLITICAL CONSIDERATIONS}

U.S. public opinion plays a significant role in internal and external politics. In democratic countries, politicians are influenced by public opinion; similarly, U.S. public opinion can impact the politics of U.S. foreign policy. 
For instance, after many examples showed that the Syrian regime used chemical weapons against its civilians, western countries were pressured to consider military intervention. However, the parliament in some countries voted against military action, such as the U.K. After David Cameron's government tried to take military action to counter Bashar Al-Assad and gave a proposal to the British parliament to vote on it, on 27 August 2013, the British House of Commons refused the British Prime Minister's proposal to act in Syria. In addition, this made Barack Obama reluctant to ask Congress to operate in Syria (Codner, 2014).

Consequently, public opinion and parliaments, which the people elect, may impact countries' intervention policies. The U.S. public opinion also affects U.S. intervention against ISIS because there is a disagreement with the domestic ideas. As a result, Obama's government changed its policy of full intervention to an incomplete one towards ISIS.

Furthermore, public support for military intervention has changed over time. For example, the Iraq war in 2003 made a controversial argument among U.S. public opinion. The Iraq war has impacted U.S. military intervention. According to Eichenberg (2005), from the beginning of the Iraq war on 19 March 2003 until 01 May 2003, the U.S. public support for the war was 72 percent. After 01 May, the U.S. public support for war decreased steadily. Since combat finished, support for the war has been 52 percent.

Nevertheless, by June 2005, average citizen support had decreased below 50 percent (Eichenberg, 2005, p: 140). Thus, it is argued that support for the war among the U.S. public has changed. U.S. citizen support is also a significant factor in changing U.S. military intervention. This will be another reason that the U.S. has not fully intervened in the case of ISIS.

Moreover, the intervention's objective and the resulting success or failures are significant for supporting war with the citizens. People want the military mission when its objective is clear and successful. Eichenberg (2005) states that public support for military operations is conditioned by the kind of objective for which force is used. He also says that when the military mission is successful, public support for war increases. However, public support for the war declines if the military action failed (Eichenberg, 2005, p: 141). As a result, this shows that the military mission's objective and resulting success or failure play a key role in citizen support for the war.

Additionally, the U.S. became tired of military intervention because Americans know about the high costs of military intervention. In the past decades, American lost many troops and spent huge money on military operations, particularly in the Afghan war in 2001 and the Iraq war in 2003. This hinders Washington from intervening in other countries fully. According to Eichenberg (2005), public support for sending troops is often lower when the prospect of casualties is mentioned in the question. Also, according to The Financial Express (2014), "The majority of Americans seems to be fed up with sending their boys and girls to foreign countries to fight a war, no matter what." This pushes Obama not to send American troops to foreign countries and bring their dead bodies to America. American president understands the high costs of military operations, so he cares about this cost. He tries to intervene in countries at the lowest cost possible (The Financial Express, 2014, p: 1). As a result, this shows that casualties have a significant impact on the politics of U.S. intervention. It can be argued that the high costs of military intervention and losses are another reason to ban the U.S. from entire military operations against ISIS. Americans do not want to lose too many troops and spend huge money.

What is more, domestic political competition has a significant impact on international crises. In democratic countries, there are two main actors, which are a government and an opposition. Both of them have a considerable role in global conflict. Although opposition parties are not the main actors to start a war or operate in other countries, they can affect governments to intervene in countries or ban governments from waging war. This view is supported by Schultz (1998), who writes that "... a government with a domestic competitor has less opportunity to misrepresent its preferences, and the dangers associated with asymmetric information are consequently lower". He states that war is lower when both government and opposition parties send informative signals than when the government is the only voice in the country. Oppositions are not leading players but a passive source of costs. It is a fact that opposition parties decide whether to support the government or not in military intervention. For instance, in the American experience in the Gulf War, numerous Democratic representatives opposed military forces (Schultz, 1998, p: 830). Hence, this shows that in democratic countries, opposition parties can support or hamper governments in conducting overseas military operations. The U.S. opposition party can also influence the U.S. intervention policy and help Obama's government make the slightest mistake in international affairs, especially in the ISIS case. This will be another reason that the politics of U.S. intervention are reluctant towards ISIS.

However, this does not mean that the U.S. does not intervene in countries anymore. For example, although U.S. public opinion presses its politicians to give up on 
intervention, the U.S. has been threatened by terrorism; this pushes America to fight against I.S. A prominent example is September 11, 2001, which Al-Qa'ida organized nineteen terrorists to control four civil aircraft. Two of them crashed into both World Trade Center towers in New York. After two towers were destroyed, a third aircraft hit the Pentagon, while the fourth aircraft crashed in Pennsylvania because the passengers tried to stop the hijackers. After that, on September 20, Bush launched a 'global war on terrorism.' Also, this has affected the U.K. because sixtyseven British were killed among three thousand people. In addition, in 2005, fifty-two people died in the London Underground bombings (Codner, 2014). This has impacted the U.K. to fight against terrorism as well. Also, Keohane (2005) states that Prime Minister Tony Blair organized a coalition to counter-terrorism (Keohane, 2005). Consequently, the U.S. and the U.K. have focused on international security issues, especially terrorism. For this reason, the United States fight against the Islamic state because the U.S. knows that ISIS as a terrorist group is a global threat; ISIS even affects some states far more than others.

\section{REGIONAL AND INTERNATIONAL CONSIDERATIONS}

Regional and international relations between countries have a crucial influence on the order of systems in the world. The U.S. has often tried to impact almost every regional and international country by its politics. The prime example was the Iraq war in 2003 when the U.S. announced chemical weapons in Iraq. The U.S. quite succeeded in collecting regional and international support to intervene in Iraq in 2003. However, some countries such as Russia and China always oppose U.S. military intervention. For instance, Lauria and Levinson (2012) state that after Arab spring 2011, the U.S. tried to collect support in the United Nations Security Council to change the Bashar Al Assad Regime in Syria, but two permanent members of the United Nations Security Council, which are Russia and China, vetoed the U.S.' project. They refused it (Lauria \& Levinson, 2012). It is worth highlighting regional and international considerations in separate ways to understand the U.S. intervention against I.S.

\section{REGIONAL CONSIDERATIONS}

Noted that Iran had developed ties with Iraq since 2003. Iraqi Prime Minister Maliki led many visits to Iran; since the 1979 revolution, Ahmadinejad became the first Iranian president to visit Iraq in March 2008.

Additionally, in January 2010, Iran and Iraq had signed more than a hundred cooperation treaties
(Esfandiary \& Tabatabi, 2015, p: 4). Furthermore, according to Esfandiary and Tabatabai (2015), Iran helps and supports Syria politically, militarily, and financially (Esfandiary \& Tabatabai, 2015, p: 8). It shows that there is a strong relationship between Iran, Iraq, and Syria. The U.S. is not happy with the Iran-Iraq-Syria relationship because America has a severe problem with Iran. Besides, Iran-Iraq-Syria relations are also dangerous for American geostrategic policy in the Middle East. Consequently, the U.S. has not fully intervened against I.S. as this shows that the U.S. wants to disconnect geographically among Iran, Iraq, and Syria and break down their relationship.

Turkey is one of the most critical countries in the Middle East. Turkey is a member of NATO and Washington's key ally in the region. However, Turkey has been unwilling to take part in combat operations against ISIS. The U.S. tries to convince Turkey to play a more active role against I.S. Philips (2014) notes that Turkey is a problematic country for Obama's campaign against ISIS. Because of Turkey's absence of response to I.S. aggression, suspicion increased on Turkey's reliability. Turkey is reluctant to join Obama's coalition against I.S. Although Turkey permitted U.S. warplanes to operate from Incirlik Air Force and promised to establish a base to train the Syrian opposition, Turkey has failed to fulfill its promises.

Furthermore, Turkey financially and logistically supports I.S., and Turkey also has transited Jihadis from Turkey to Syria (Phillips, 2014, p: 355). Moreover, Friedman notes that "Erdogan stands for authoritarianism, press intimidation, crony capitalism, and quiet support for Islamists including ISIS" (Phillips, 2014, p: 355). Hence, it can be argued that although Turkey is a member of NATO and the U.S. key ally in the region, Turkey is reluctant to fight and join the military campaign against I.S. It may be another reason why Washington has not fully intervened against the Islamic State.

Kurdish forces, which called Peshmerga, on the ground and American forces with its allies in the air fight against I.S. Because Kurdish forces combat against these terrorists in Iraq and Syria, the U.S. and its partners may not feel that it is so necessary to send their militaries to Iraq and Syria. American President Barack Obama (2014) (cited in The White House, 2014) states that American pilots have successfully destroyed the Islamic State weapons and equipment types. Kurdish troops on the ground battle against ISIS to defend their territory, and American airstrikes aid Kurdish soldiers as they wage their fight (The White House, 2014, p: 1). It demonstrates that the U.S. does not want to send troops to combat ISIS because the Kurdish forces will fight 
against it on the ground. As a result, this is another reason why American has not fully intervened in the Islamic State.

\section{INTERNATIONAL CONSIDERATIONS}

The U.S. usually makes a coalition and alliance to intervene in countries and groups. It does not mean that the U.S. cannot intervene in countries alone; instead, American's partnership with other countries gives legitimacy to the U.S. intervention. America often depends on some powerful nations to intervene in other countries. For example, the United Kingdom is one of the best and nearest countries to the United States, and the U.K. is an ally of the U.S. to intervene in other countries. After the U.S. attacked Al-Qa'ida on 11 September 2001, Tony Blair supported the U.S. to fight against terrorism. According to Keohane (2005), "Within an hour or so of the 11 September 2001 attack on the United States - involving the largest ever British loss of life from terrorism - Blair positioned the United Kingdom as the closest ally and supporter of the United States, marking the multiple ties between the two countries" (Keohane, 2005, p: 62). Also, to stop ISIS, the U.S. led the coalition battle with some countries' forces. In addition, more than sixty countries with Kurdish forces have a coalition to fight against I.S., for example, the United States, the United Kingdom, France, Germany, Australia, Qatar, and Saudi Arabia (U.S. Department of State, 2014). Consequently, these show that the U.S. often tries to intervene in countries with its allies, giving the U.S. international legitimacy. It can be argued that if all countries support the U.S. to operate against ISIS, the U.S. may fully intervene against ISIS.

Nevertheless, Russia and China have doubts about American intervention in some countries in the world. They disagree with the politics of American intervention because they think America tries to control the world by intervening in other countries, especially countries that, politically, economically, and geographically, are friends and close to Russia and China (Connable \& Dobbins, 2020). In addition, Russia and China usually refuse American intervention in countries, Syria, for example. According to Lauria and Levinson (2012), Russia and China vetoed the United Nations Security Council's resolution for regime change in Syria (Lauria \& Levinson, 2012). As a result, this shows that Russia and China often hinder U.S. intervention in countries. It can be argued that this is another reason why the politics of U.S. intervention are fuzzy towards ISIS.

\section{CONCLUSIONS}

To conclude, as this study has shown, the politics of U.S. intervention have changed over time because of its domestic political considerations and regional and international considerations. For these reasons, the U.S. has not conducted ground military operations in war against ISIS and has limited its operations to the airstrikes. This paper has discussed the reasons for changing the U.S. intervention policy, especially towards the Islamic State. The U.S. policy of intervention has changed from one time to another time. For example, America fully intervened in Afghanistan in 2001 and Iraq in 2003, in which the U.S. used its ground troops, air powers, and warships. However, the U.S. did not fully intervene in Bosnia in 1995 and Kosovo in 1999, in which the U.S. attacked them with its air forces, and it did not use its ground soldiers. Like the Kosovo war, the U.S. has not fully intervened in the war whereby the U.S. has operated against ISIS only by bombing without using its ground troops. Kurth (2005) states that Americans may look forward to fast and cheap military intervention and humanitarian intervention successes (Kurth, 2005).

This study has found that, generally, three factors brought change to the politics of U.S. intervention, namely the U.S. domestic political considerations, regional and international considerations. In domestic political considerations, U.S. public opinion has a significant role in the politics of U.S. intervention. It is to be noted that the U.S. public support for wars has changed over time. This has been influenced by several key factors: the intervention's objective, the resulting success or failure of the U.S. intervention, and the high cost or casualties of military intervention. Moreover, the U.S. domestic political competition plays a key role in the politics of U.S. intervention. The U.S. domestic political opinion presses the U.S. policy of intervention to stop intervening in countries. However, the U.S. intervenes in wars against military groups such as the Islamic State Caliphate because the U.S. has been threatened by terrorism.

Regional and international considerations are other factors that the U.S. has not fully intervened against ISIS. In regional considerations, the U.S. geostrategic policy is one reason for this change. The USA is not happy with a strong Shi' is relation, which Iran tries to control and lead this Shiite relationship. Also, although Turkey is a member of NATO and American's key ally in the region, Turkey is reluctant to fight against ISIS. Turkey financially and logistically supports I.S., and it is also transited Jihadists from Turkey to Syria. Moreover, the U.S. might not deem it necessary to send its soldiers to fight against ISIS in Iraq and Syria because Kurdish forces combat against it. Nonetheless, in international considerations, Russia and China usually deter the U.S. from intervening in countries. 
The findings of this study suggest that the U.S. should change its policy of intervention from one time to another time, and the U.S. should change its military tactics from one war to another war because its enemies are changing. Its enemies' war tactics (such as ISIS' tactics) are different as well. It is recommended that the American government understand how its domestic and international politics view intervention policy against I.S. regarding the future. If all countries support the U.S. to operate against ISIS, the U.S. will fully intervene against it and win the war. However, suppose the U.S. cannot change its intervention policy and cannot collect internal and external support, particularly towards I.S. In that case, the U.S. will fail to intervene in I.S. war fully, and it cannot win the war. The U.S. will lose its position in international politics.

\section{REFERENCES}

Ben Connable, James Dobbins, Howard J. Shatz, Raphael S. Cohen, Becca Wasser, Weighing U.S. Troop Withdrawal from Iraq, RAND corporation, 2020, AVAILABLE AT: Weighing U.S. Troop Withdrawal from Iraq: Strategic Risks and Recommenda tions | RAND

Codner, M. (2014) ‘The Two Towers, 2001-13', Johnson, A. (eds.)`Wars in Peace British Military Operations since 1991'. London: Royal United Services Institute for Defense and Security Studies (RUSI), pp. $49-87$.

Eichenberg, R. (2005) `Victory Has Many Friends: U.S.Public Opinion and the Use of Military Forde, 1981-2005', International Security, 30(1), pp. 140-177.

Esfandiary, D. and Tabatabai, A. (2015) 'Iran's ISIS policy,' International Affairs, 91(1), pp. 1-15.

Jentleson, B. and Britton, R. (1998) 'Still Pretty Prudent:Post-Cold War American Public Opinion on the Use of Military Force,' The Journal of Conflict Resolution, 42(4), pp. 395-417.

Keohane, D. (2000) 'The debate on British policy in the Kosovo conflict: An assessment,' Contemporary Security Policy, 21(3), pp.78-94.

Keohane, D. (2005) 'The United Kingdom,' in Danchev, A. and MacMillan, J. (eds.) The Iraq War and Democratic Politics. New York: Routledge, pp. 59-76.

Kurth, J. (2005) 'The Iraq War and Humanitarian Intervention,' Globa 1 Dialogue, 7(1/2), pp. 97.

Lauria, J., and Levinson, C. (2012) 'Russia, China Veto U.N. Resolution on Syria,' Dow Jones \& Company Inc, New York, N.Y., 04 February 2012, pp. n/a.

MacMillan, J. (2013) 'Intervention and the ordering of the modern world,' Review of InternationalStudies,39(5), pp. 1039-1056.

Mint (2014) 'U.S. warplanes strike Islamic State artillery in Iraq', H.T. Media Ltd, New Delhi, 09 August 2014.

Phillips, D. (2014) 'ISIS Crisis,' American Foreign Policy Interests, 36(6), pp. 351-360.

Samuel P. Huntington, who are we? the challenges to American national identity, Simon and Schuster, New York, 2004.

Schultz, K. (1998) `Domestic Opposition and Signaling in Internationa 1 Crises,' The American Political Science Review, 92(4), pp. 829-844.
Smith, R. (2006) 'Introduction: Understanding Force' in the utility of force: the art of war in the modern world. London: Pengu in, pp. $1-26$.

Sprusansky, D. (2014) ‘Understanding ISIS: frequently asked questions. (Special Report)', Washington Report on Middle East Affairs, 33(7), pp. 19.

The Financial Express (2014) 'President Obama faces ISIS,' H.T. Media Ltd, Dhaka, 14September 2014.

The White House (2014) 'Statement by the President on Iraq'. Retrieved from The White House Office of the Press Secretary. Available at: http://www.whitehouse.gov/the-pressoffice/2014/08/09/statement-president-iraq (Accessed: 20 February 2015).

U.S. Department of State (2014) 'Joint Statement Issued by Partners at the Counter-ISIL Coalition Ministerial Meeting.' Retrieved from U.S. Department of State (Office of the Spokesperson). Available at: http://www.state.gov/r/pa/prs/ps/2014/12/234627.htm (Accessed: 03 December 2014). 